\title{
KEDUDUKAN BENDA JAMINAN YANG DIBEBANI HAK TANGGUNGAN APABILA TERJADI EKSEKUSI DALAM HAL DEBITUR WANPRESTASI
}

\author{
SJAIFURRACHMAN \\ Fakultas Hukum, Universitas Wiraraja Sumenep \\ sjafurrachman@yahoo.com \\ ABSHORIL FITHRY \\ Fakultas Hukum, Universitas Wiraraja Sumenep \\ abshorilfithry@ rocketmail.com
}

\begin{abstract}
ABSTRAK
Orang melakukan perikatan dengan yang lain guna memenuhi kebutuhan hidupnya dengan cara barter (penukaran barang dengan barang), lalu berubah menjadi penukaran barang dengan uang barang dan kemudian berganti menjadi barang dengan uang.

Wanprestasi adalah ketiadaan suatu prestasi didalam hukum perjanjian, berarti suatu hal yang harus dilaksanakan sebagai isi dari suatu perjanjian. Barangkali daslam bahasa Indonesia dapat dipakai istilah "pelaksanaan janji untuk prestasi dan ketiadaan pelaksanaannya janji untuk wanprestasi.
\end{abstract}

Kata Kunci : Benda Jaminan, hak tanggungan, eksekusi, wanprestasi.

\section{A. PENDAHULUAN}

Indonesia adalah salah satu Negara yang menganut sistem Demokrasi yaitu dari rakyat oleh rakyat dan untuk rakyat. Di dalam mewujudkan Negara berkembang Indonesia menjalani sistem-sistem yang ada baik yang tertulis ataupun yang tidak tertulis.

Orang melakukan perikatan dengan yang lain guna memenuhi kebutuhan hidupnya dengan cara barter (penukaran barang dengan barang), lalu berubah menjadi penukaran barang dengan uang barang dan kemudian berganti menjadi barang dengan uang.

Akibat kian hari kian banyak pula kebutuhan yang harus dipenuhi yang tidak diiringi dengan jumlah pendapatan, maka lahirlah ingkar janji dari suatu kesepakatan yang telah dibuat yang dinamakan Wanprestasi yang tentunya tidak lain merugikan pihak kreditur, baik perjanjian itu berupa sepihak (cuma-cuma) maupun timbalbalik (atas beban).

Upaya manusia untuk memenuhi berbagai kepentingan bisnis, diantaranya adalah mewujudkannya dalam bentuk kontrak bisnis. Kontrak atau contracts (dalam bahasa Inggris) dan overeenskomst (dalam Bahasa Belanda) dalam pengertian yang lebih luas kontrak sering dinamakan juga dengan istilah perjanjian . Istilah "kontrak" atau "perjanjian" dalam sistem hukum nasional memiliki pengertian yang sama, seperti halnya di Belanda tidak dibedakan antara pengertian "contract" dan "overeenkomst". (Salim HS. 2004:30). Kontrak adalah suatu perjanjian (tertulis) antara dua atau lebih orang (pihak) yang menciptakan hak dan kewajiban untuk melakukan atau tidak melakukan hal tertentu. Dalam hukum kontrak sendiri terdapat asas yang dinamakan kebebasan berkontrak. 
Menurut Pasal 1338 Ayat (1) KUH Perdata menyatakan bahwa semua perjanjian yang dibuat secara sah berlaku sebagai undangundang bagi mereka yang membuatnya.

Bertitik tolak pada pasal 1313 KUH Perdata menyatakan bahwa "perjanjian adalah suatu perbuatan hukum yang berisi dua" (een tweezijdige rechtshandeling) untuk menimbulkan persesuaian kehendak guna melahirkan akibat hukum. Yang dimaksud dengan satu perbuatan hukum yang berisi dua ialah penawaran (aanbod/offer) dan penerimaan (aanvaarding acceptance).( Pasal 1338 Kitab Undang-Undang Hukum Perdata). Penawaran dan penerimaan itu masing-masing pada hakekatnya adalah perbuatan hukum. Sedangkan yang dimaksud dengan perbuatan hukum adalah perbuatan subyek hukum yang didasarkan pada kehendak yang dinyatakan untuk menimbulkan akibat hukum yang dikehendaki dan diakui oleh hukum. Berarti masing-masing pihak seyogyanya mempunyai kebebasan kehendak. Itulah sebabnya Buku III KUH Perdata dikatakan menganut sistem terbuka. Tetapi kebebasan kehendak tersebut dalam kenyataanya seringkali didapati salah satu pihak yang menentukan syarat didalam suatu kontrak, sedangkan pihak lain hanya dapat menerima atau menolak (misalnya dalam kontrak standar: syarat umum dari bank, syarat penyerahan dari produsen, dan sebagainya).

Istilah perjanjian dalam Pasal 1313 Kitab Undang Undang Hukum Perdata, perjanjian adalah suatu perbuatan dengan mana satu orang atau lebih mengikatkan dirinya terhadap satu orang lain atau lebih. Oleh karena itu, tidak salah jika Kartini Muljadi dan Gunawan Widjaja dalam bukunya Perikatan yang Lahir dari Perjanjian.menyebutkan suatu perjanjian adalah suatuperbuatan, antara sekurangkurangnya dua orang (jadi dapat lebih dari dua orang), perbuatan tersebut melahirkan perikatan diantara dua pihak yang berjanji tersebut. Unsur perjanjian dilihat dari pasal 1313 KUH Perdata yaitu :

1. Ada para pihak

2. Ada persetujuan antara pihak-pihak tersebut

3. Ada tujuan yang akan dicapai

4. Ada prestasi yang akan dilaksanakan

5. Ada bentuk tertentu,baik lisan maupun tulisan

6. Ada syarat-syarat tertentu.

Terjadinya prestasi, wanprestasi, keadaan memaksa, fiudusia, dan hak tangunggan dikarenakan hukum perikatan menurut Buku III B.W ialah: suatu hubungan hukum (mengenai kekayaan harta benda) antara dua orang, yang memberi hak pada yang satu untuk menuntut barang sesuatu dari yang lainnya, sedangkan orang lainnya ini diwajibkan untuk memenuhi tuntutan itu. Oleh karena sifat hukum yang termuat dalam Buku III itu selalu berupa suatu tuntutmenuntut maka Buku III juga dinamakan hukum perhutangan. Pihak yang berhak menuntut dinamakan pihak berpiutang atau "kreditur" sedangkan pihak yang wajib 
memenuhi tuntutan dinamakan pihak pelaksanaannya tentunya pengadilan berhutang atau "debitur".

\section{B. PEMBAHASAN}

Eksekusi obyek hak tanggungan diatur dalam Pasal 20 ayat 1 Undang-Undang Hak Tanggungan, yang mengatur bahwa apabila debitur cidera janji, maka obyek hak tanggungan dapat dieksekusi dengan dua cara yaitu : Eksekusi Atas Kekuasaan Sendiri (Parate Eksekusi) dan fiat eksekusi yaitu ekekusi melalui pengadilan.

Berdasarkan Pasal 6 UUHT, kreditur pemegang hak tanggungan pertama mempunyai hak untuk menjual obyek hak tanggungan atas kekuasaan sendiri melalui pelelangan umum, dari hasil pelelangan tersebut kreditur mengambil untuk pelunasan piutangnya, atau yang biasa disebut dengan parate eksekusi. Penjelasan Pasal 6 UUHT memberikan ketentuan, bahwa parate eksekusi tersebut didasarkan pada yang diperjanjikan dalam suatu Akta Pemberian Hak Tanggungan (APHT). Adanya perbedaan yang demikian, menurut Sjahdeini, Pasal 6 UUHT menentukan bahwa untuk melakukan parate eksekusi tidak harus diperjanjikan terlebih dahulu, namun Sjahdeini tetap mengakui bahwa terdapat ketidak-serasian antara Pasal 6 UUHT dengan Penjelasan Pasal 6 UUHT.

Pelaksanaan pelunasan piutang kreditur yang dilakukan oleh Pengadilan Negeri berdasarkan kekuatan eksekutorial Sertifikat Hak Tanggungan yang merupakan pelaksanaan Pasal 224 HIR, dan dalam melakukan tindakan hukum yang berbentuk conservatoire beslag dan executie beslag. Dengan dcmikian perlawanan terhadap eksekusi obyek hak tanggungan hanya mungkin dilakukan terhadap eksekusi yang dilakukan berdasarkan kekuatan eksekutorial Sertifikat Hak Tanggungan (Pasal 20 ayat (1) huruf $b$ UUHT) dan tidak dapat dilakukan terhadap eksekusi hak tanggungan berdasarkan parate eksekusi. Hal ini disebabkan parate eksekusi dalam pelaksanaannya tidak melibatkan Pengadilan Negeri, maka eksekusi obyek hak tanggungan berdasarkan parate eksekusi (Pasal 20 ayat (I) huruf a UUHT) tidak dimungkinkan diajukan perlawanan, namun diajukan melalui gugatan biasa.

Perlawanan terhadap eksekusi obyek hak tanggungan berdasarkan kekuatan eksekutorial Sertifikat Hak Tanggungan dapat dilakukan oleh pihak ketiga (derden verzet) maupun oleh debitur itu sendiri (partij verzet).Kedua perlawanan tersebut diajukan ke Pengadilan Negeri yang berwenang, yaitu Pengadilan Negeri yang melakukan sita eksekusi (Pasal 195 ayat 6 HIR / Pasal 206 ayat (6) RBg).Perlawanan yang dilakukan oleh pihak ketiga (derden verzet) harus atas dasar hak milik, dengan demikian perlawanan (terhadap eksekusi berdasarkan kekuatan eksekutorial Sertifikat Hak Tanggungan), dalam persidangan pelawan harus dapat membuktikan dengan dasar hak milik, karena hanya pemegang hak milik yang dapat 
rnengajukan perlawanan terhadap eksekusi obyek hak tanggungan yang telah dilakukan oleh Pengadilan Negeri.

Pada praktek dapat juga terjadi perlawanan yang disebabkan oleh putusan atau penetapan Pengadilan yang menimbulkan kerugian yang tidak berdasarkan hak milik, tetapi dengan mendasarkan Pasal 378 Rv, Ini dapat terjadi misalnya perlawanan bahwa eksekusi obyek hak tanggungan tidak sah karena jumlah hutang yang diminta untuk eksekusi melebihi pokok hutang yang disebutkan dalam akta karena di dalamnya diperhitungkan denda. Perlawanan yang diajukan oleh debitur sendiri (jiartij verzet) dilakukan berdasarkan alasan adanya cacat formal atau material yang melekat pada Sertifikat Hak Tanggungan, dan tidak menyangkut pokok materi hubungan hukum antara debitur dengan kreditur. Apabila dalam perlawanan yang telah diajukan dikabulkan dan eksekusi ditolak, dan penyelesaian hutang-piutang dilakukan dengan cara melakukan gugatan ke Pengadilan Negeri, namun apabila cacat formal maupun material tidak ditemukan, maka perlawanan ditolak dan eksekusi diteruskan sampai pelelangan dilakukan untuk pelunasan utang-piutang.

Eksekusi berdasarkan kekuatan eksekutorial ada sisi lebih dan kekurangannya. Kelebihan eksekusi berdasarkan kekuatan eksekutorial Sertifikat Hak Tanggungan yang melibatkan Pengadilan Negeri, yaitu meskipun ada perlawanan, Pengadilan dapat melaksanakan eksekusi. Bagi pemenang lelang, pengosongan obyek hak tanggungan berdasarkan pasal 224 HIR akan lebih mudah dan pasti dibandingkan dengan parate eksekusi yang terlebih dahulu harus mengajukan gugatan. Sedangkan kelemahannya adalah, apabila memang tidak ada masalah dalam Sertifikat Hak Tanggungan yang menyangkut syarat formil atau nyata materiil, akan memerlukan waktu dan biaya yang tidak sedikit, dibandmg parate eksekusi. Walaupun masing-masing eksekusi tersebut terdapat kelemahan dan kelebihan, akan tetapi preferensi kreditur pemegang hak tanggungan tetap dijamin untuk kepastian hukumnya.

Wujud prestasi yang lainnya adalah "berbuat sesuatu" dan "tidak berbuat sesuatu". Berbuat sesuatu adalah melakukan suatu perbuatan yang telah ditetapkan dalam perjanjian.(Zulfi Chairi, 2005:15) Sedangkan tidak berbuat sesuatu adalah tidak melakukan sesuatu perbuatan sebagaimana juga yang telah ditetapkan dalam perjanjian, manakala para pihak telah menunaikan prestasinya maka perjanjian tersebut akan berjalan sebagaimana mestinya tanpa menimbulkan persoalan. Namun kadangkala ditemui bahwa debitur tidak bersedia melakukan atau menolak memenuhi prestasisebagaimana yang telah ditentukan dalam perjanjian.

Salah satu unsur dari suatu perikatan adalah adanya suatu isi atau tujuan perikatan, yakni suatu prestasi yang terdiri dari 3 (tiga) macam: 
a. Memberikan sesuatu, misalnya sudah ditentukan dalam perjanjian, maka membayar harga, menyerahkan menurut Pasal 1238 KUHPerdata, barang. debitur sudah dianggap wanprestasi dengan

b. Berbuat sesuatu, misalnya lewatnya waktu pemenuhan prestasitersebut. memperbaiki barang yang rusak, Sedangkan bila tenggang waktunya tidak membangun rumah, melukis suatu dicantumkan dalam perjanjian, maka lukisan untuk pemesan.

c. Tidak berbuat sesuatu, misalnya perjanjian tindak akan mendirikan suatu bangunan, perjanjian tidal alan menggunakan merk dagang tertentu.( Ibid.)

Prestasi dalam suatu perikatan atau perjanjian pada Pasal 1234 KUHPerdata tersebut harus memenuhi syarat-syarat:

a. Suatu prestasi harus merupakan suatu prestasi yang tertentu, atau sedikitnya dapat ditentukan jenisnya, tanpa adaya ketentuan sulit untuk menentukan apakah debetur telah memenuhi prestasi atau belum.

b. Prestasi harus dihubungkan dengan suatu kepentingan. Tanpa suatu kepentingan orang tidak dapat mengadakan tuntutan.

c. Prestasi harus diperbolehkan oleh Undang-Undang, kesusilaan dan ketertiban umum.

d. Prestasi harus mungkin dilaksanakan.

Dalam hal wujud prestasinya "memberikan sesuatu", maka perlu pula dipertanyakan apakah di dalam perjanjian telah ditentukan atau belum mengenai tenggang waktu pemenuhan prestasinya. dipandang perlu untuk terlebih dahulu memperingatkan debitur guna memenuhi kewajibannya, dan jika tidak dipenuhi, maka ia telah dinyatakanwanprestasi.

Surat peringatan kepada debitur tersebut dinamakan somasi, dan somasiinilah yang digunakan sebagai alat bukti bahwa debitur telah wanprestasi. Untuk perikatan yang wujud prestasinya "tidak berbuat sesuatu" kiranya tidak menjadi persoalan untuk menentukan sejak kapan seorang debitur dinyatakan wanprestasi, sebab bila debitur melakukan sesuatu perbuatan yang dilarang dalam perjanjian maka ia dinyatakan telah wanprestasi.

Wanprestasi berarti debitur tidak melakukan apa yang dijanjikannya atau ingkar janji, melanggar perjanjian serta melakukan sesuatu yang tidak boleh dilakukannya. Perkataan wanprestasi berasal dari bahasa Belanda yang berarti prestasi buruk. Debitur dianggap wanprestasi bila ia memenuhi syarat-syarat di atas dalam keadaan lalai maupun dalam keadaan sengaja. Wanprestasi yang dilakukan debitur dapat berupa 4 (empat) macam:

1. Tidak melakukan apa yang disanggupi akan dilakukan; 
2. Melaksanakan apa yang dijanjikannya, tetapi tidak sebagaimana dijanjikan;

3. Melakukan apa yang dijanjikan tetapi terlambat;

4. Melakukan sesuatu yang menurut perjanjian tidak boleh dilakukannya.

Ada pendapat lain yang menyatakan mengenai syarat-syarat terjadinya wanprestasi, yaitu:

1. Debitur sama sekali tidak berprestasi, dalam hal ini kreditur tidak perlu menyatakan peringatan atau teguran karena hal ini percuma sebab debiturmemang tidak mampu berprestasi;

2. Debitur berprestasi tidak sebagaimana mestinya, dalam hal ini debitur sudah beritikad baik untuk melakukan prestasi, tetapi ia salah dalam melakukan pemenuhannya;

3. Debitur terlambat berprestasi, dalam hal ini debitur masih mampu memenuhi prestasi namun terlambat dalam memenuhi prestasi tersebut.

Akibat hukum dari debitur yang telah melakukan wanprestasi adalah hukuman atau sanksi sebagai berikut:

1. Membayar kerugian yang diderita oleh kreditur atau dengan singkat dinamakan ganti-rugi;

2. Pembatalan perjanjian atau juga dinamakan pemecahan perjanjian;
3. Peralihan risiko. Benda yang dijanjikan obyek perjanjian sejak saat tidak dipenuhinya kewajiban menjadi tanggung jawab dari debitur;

4. Membayar biaya perkara, kalau sampai diperkarakan di depan hakim.

Disamping debitur harus menanggung hal tesebut diatas, maka yang dapat dilakukan oleh kreditur dalam menghadapi debitur yang wanprestasi ada lima kemungkinan sebagai berikut diatur dalam Pasal 1276 KUHPerdata:

1. Dapat menuntut pemenuhan perjanjian, walaupun pelaksanaannya terlambat;

2. Dapat menuntut penggantian kerugian, berdasarkan Pasal 1243 KUHPerdata, ganti rugi tersebut dapat berupa biaya, rugi atau bunga;

3. Dapat menuntut pemenuhan dan penggantian kerugian;

4. Dapat menuntut pembatalan atau pemutusan perjanjian; dan

5. Dapat menuntut pembatalan dan penggantian kerugian.

Pada debitur terletak kewajiban untuk memenuhi prestasi dan jika ia tidak melaksanakan kewajibannya tersebut bukan karena keadaan memaksa maka debitur dianggap melakukan ingkar janji. Wanprestasi adalah keadaan dimana debitur tidak memenuhi prestasi (ingkar janji) yang telah diperjanjikan dari hal tersebut muncullah 
resiko yang harus ditanggung oleh debitur. (R.Subekti, 2000:49).

Risiko ialah kewajiban memikul kerugian yang disebabkan karena suatu kejadian diluar kesalahan salah satu pihak. Barang yang diperjual belikan musnah diperjalanan karena ada suatu kecelakaan misalnya perahu yang mengangkut barang itu karam. Barang yang dipersewakan habis terbakar selama waktu dipersewakannya. Siapakah yang harus memikul kerugian-kerugian itu, Inilah yang disebut risiko.

Setiap Kreditor pasti mempunyai jaminan kebendaan pelunasan utang dari debitor baik yang bersifat umum maupun yang bersifat khusus. Apabila Kreditor tidak meminta jaminan secara khusus ketika melakukan perjanjian utang-piutang dengan Debitor, maka berdasarkan Pasal 1131 KUHPerdata secara otomatis kreditor mempunyai jaminan umum pembayaran utang dari harta benda milik debitor. Pelunasan hutang adalah terdiri dari pelunasan bagi jaminan yang bersifat umum dan jaminan yang bersifat khusus.

Jaminan yang bersifat kebendaan adalah jaminan yang berupa hak mutlak atas sesuatu benda, yang mempunyai ciri-ciri mempunyai hubungan langsung atas benda tertentu dari debitur, dapat dipertahankan terhadap siapa pun, selalu mengikuti bendanya dan dapat diperalihkan (contoh: hipotik, hak tanggungan, gadai, dan lain-lain).

Jaminan kebendaan dapat diadakan antara kreditur dengan debiturnya, tetapi juga dapat diadakan antara kreditur dengan seorang pihak ketiga yang menjamin dipenuhinya kewajiban-kewajiban dari si berutang (debitur).

Pemberian jaminan kebendaan selalu berupa menyendirikan suatu bagian dari kekayaan seseorang, si pemberi jaminan, dan menyediakannya guna pemenuhan (pembayaran) kewajiban (utang) dari seorang debitur. Kekayaan tersebut dapat berupa kekayaan si debitur itu sendiri atau kekayaan pihak ketiga. "Pemberian jaminan kebendaan ini kepada si berpiutang (kreditur) tertentu, memberikan kepada si berpiutang tersebut suatu hak privilege (hak istimewa) terhadap kreditur lainnya.

\section{PENUTUP}

Pengaturan Hukum tentang eksekusi terhadap Benda jaminan ketika debitur cidera janji (wanprestasi) prosesnya dilakukan melalui parate eksekusi dan eksekusi berdasarkan kekuatan eksekutorial sertifikat hak tanggungan. Sedangkan dalam hal debitur telah dinyatakan pailit, proses hukumnya dilaksanakan oleh kurator dibawah kuasa hakim pengawas, melalui tahapan proses hukum yaitu; pengamanan dan penyegelan harta pailit oleh kurator, pencocokan dan kegiatan verifikasi piutang, penawaran damai terhadap kreditur, dan terakhir penyelesaian dan Pembagian hasil Eksekusi Harta Pailit. Akibat hukum dari debitur yang telah melakukan wanprestasi adalah hukuman atau sanksi berupa membayar kerugian yang diderita oleh kreditur (ganti rugi), pembatalan 
perjanjian, peralihan resiko. Benda yang dijanjikan obyek perjanjian sejak saat tidak dipenuhinya kewajiban menjadi tanggung jawab dari debitur dan membayar biaya perkara, kalau sampai diperkarakan di depan hakim. Disamping debitur harus menanggung hal tesebut diatas, maka yang dapat dilakukan oleh kreditur dalam menghadapi debitur yang wanprestasi ada lima kemungkinan sebagai berikut (Pasal 1276 KUHPerdata) yaitu memenuhi/ melaksanakan perjanjian, memenuhi perjanjian disertai keharusan membayar ganti rugi, membayar ganti rugi, membatalkan perjanjian dan Membatalkan perjanjian disertai dengan ganti rugi.

\section{DAFTAR PUSTAKA}

Satrio J. Hukum Jaminan, Hak-Hak Jaminan Kebendaan. Citra Aditya Bakti. Bandung. 2002.

Sutedi, Adrian. Hukum Hak Tanggungan. Sinar Grafika. Jakarta. 2012.

Subekti, Pokok-Pokok Hukum Perdata, Jakarta: Intermasa, 2005.

Simanjuntak, Ricardo. Teknik Perancangan Kontrak Bisnis. Jakarta: PT. Gramedia, 2006.

Satrio, J, Hukum Perjanjian (Perjanjian Pada Umumnya), Alumni Bandung, 2005.
Usman, Rachmadi. Hukum Jaminan Keperdataan. Sinar Grafika. Jakarta. 2009.

Undang-Undang Dasar 1945.

Kitab Undang-Undang Hukum Perdata

Undang-Undang Nomor 4 tahun 1996 tentang Hak Tanggungan.

Undang-Undang Nomor 5 tahun 1960 tentang Peraturan Dasar Pokok-Pokok Agraria. 